\title{
乳幼児の両前腕骨骨幹部骨折に対する牽引療法
}

\author{
宮城病院 \\ 久 賀 養一郎・宮 城 恒 夫 \\ 筑豊労災病院 \\ 梅 田 幸三郎・金 崎 克 也 \\ 井上博

\section{Skin Traction Treatment for Both-Bone Midshaft Forearm Fracture in Children} \\ by \\ Youitirou Kuga, Tsuneo Miyagi, Kozaburou Umeda \\ and Katsuya Kanesaki \\ Miyagi Orthopaedic Hospital, Fukuoka Prefecture \\ Hirosi Inoue \\ Chikuhou Rosai Hospital, Fukuoka Prefecture

\begin{abstract}
Although both-bone midshaft forearm fractures in children are treated almost exclusively by closed method. It is sometimes difficult to hold the reduced position in the cast.

Between the years 1985 and 1988, we have treated 9 cases of the both-bone midshaft forearm greenstick fractures with vertical skin traction after an average of 2.3 times of manipulative reductions. The average age of the patients at injury was 3 years and one month (range, from 1 to 7 years). The average duration of the traction was 17.9 days. There were no troubles during the traction and final results were functionally and radiologically excellent in all cases.
\end{abstract}

は じめに

乳幼児の中央 $1 / 3$ 部の両前腕骨骨折の治療の問題点 は，整復位の保持および変形の許容度である．徒手整 復は比較的容易であるが固定中に再転位を起こすこと がしばしば経験される，種々の固定上の注意や方法が 述べられているが，われわれは整復後再転位をきたし た例に垂直介達牽引を行い良好な結果を得ているので 報告する。

\section{対象と方法}

症例は昭和 60 年 1 月より昭和 63 年 12 月までの 4 年 間で, 入院し, 率引療法を行った症例は 9 例, 性別は 男 4 例, 女 5 例, 左右別では右 5 例, 左 4 例, 年令は 1 才から 7 才, 平均 3 才 1 カ月であった。受傷機転と
しては全例, 転倒し，伸展位にて手をついた例である。 骨折部位はすべて中 $1 / 3$ で骨折型は若木骨折であった。 変形は, 背側凸変形, 橈側凸変形が 5 例, 背側凸変形, 尺側凸変形が 2 例, 掌側凸変形, 尺側凸変形が 1 例, 背側凸変形のみが 1 例であった（表 1 ）。

治療に際して, 徒手整復後ギプス副子固定中に再転 位した症例に対して再度徒手整復を行い牽引療法をお こなった（図 1)，9例中 8 例が他院にて徒手整復後, ギプス副子固定中に，母親が前腕の変形を心配して来 院している. 受傷から当院受診までの期間は受傷当日 から 26 日目まで, 平均 7.7 日であった。整復回数は他 医で行われたものも含めると 2 回 6 例， 3 回 3 例，平 均 2.3 回, 牽引期間は最低 11 日最高 22 日, 平均 17.9 日であった。牽引除去後, 約 1 週間ギプス副子固定を 上肢より行い仮骨の形成状態にしたがって除去した。 


\begin{tabular}{|c|c|c|c|c|c|c|c|c|}
\hline \multirow[b]{2}{*}{ 症 例 } & 年 & 令 & \multirow[b]{2}{*}{$\begin{array}{c}\text { 経過観察 } \\
\text { 期間 }\end{array}$} & \multirow[b]{2}{*}{ 整復回数 } & \multirow[b]{2}{*}{ 牽引期間 } & \multirow[b]{2}{*}{ 初診 時変形 } & \multirow[b]{2}{*}{ 牽引後変形 } & \multirow[b]{2}{*}{ 最終経過観察時変形 } \\
\hline & 初診時 & $\begin{array}{l}\text { 最終経 過 } \\
\text { 観 察 時 }\end{array}$ & & & & & & \\
\hline 1 & $\begin{array}{l}1 \text { 才 } \\
10 \text { 力 }\end{array}$ & $\begin{array}{l}5 \text { 才 } \\
9 \text { 力月 }\end{array}$ & 1434日 & 2 回 & 15日 & $\begin{array}{l}\text { 背側凸 } 10^{\circ} \\
\text { 橈側凸 } 20^{\circ}\end{array}$ & $\begin{array}{l}\text { 背側凸 } 10^{\circ} \\
\text { 橈側凸 } 5^{\circ}\end{array}$ & $(-)$ \\
\hline 2 & $\begin{array}{l}3 \text { 才 } \\
9 \text { 力月 }\end{array}$ & $\begin{array}{l}5 \text { 才 } \\
10 \text { 力月 }\end{array}$ & 738日 & 3 回 & 22日 & $\begin{array}{l}\text { 背側凸 } 20^{\circ} \\
\text { 橈側凸 } 25^{\circ}\end{array}$ & $\begin{array}{l}\text { 背側凸 } 5^{\circ} \\
\text { 橈側凸 } 12^{\circ}\end{array}$ & $(-)$ \\
\hline 3 & $\begin{array}{l}3 \text { 才 } \\
3 \text { 力月 }\end{array}$ & 7 オ & 1387日 & 2 回 & 21日 & $\begin{array}{l}\text { 背側凸 } 5^{\circ} \\
\text { 尺側凸 } 20^{\circ}\end{array}$ & $\begin{array}{l}\text { 背側凸 5。 } \\
\text { 尺側凸10。 }\end{array}$ & $(-)$ \\
\hline 4 & $\begin{array}{c}7 \text { 才 } \\
11 \text { 力月 }\end{array}$ & $\begin{array}{l}12 \text { 才 } \\
9 \text { 力月 }\end{array}$ & 1757日 & 2 回 & 17日 & $\begin{array}{l}\text { 掌側凸15０} \\
\text { 尺側凸 } 22^{\circ}\end{array}$ & $\begin{array}{l}\text { 掌側凸15０} \\
\text { 尺側凸10． }\end{array}$ & 掌側凸 $8^{\circ}$ \\
\hline 5 & $\begin{array}{l}1 \text { 才 } \\
8 \text { 力月 }\end{array}$ & $\begin{array}{c}2 \text { 才 } \\
10 \text { カ月 }\end{array}$ & 412日 & 2 回 & 16日 & $\begin{array}{l}\text { 背側凸 } 30^{\circ} \\
\text { 橈側凸 } 10^{\circ}\end{array}$ & 背側凸 $5^{\circ}$ & $(-)$ \\
\hline 6 & $\begin{array}{l}3 \text { 才 } \\
5 \text { 力月 }\end{array}$ & $\begin{array}{l}4 \text { 才 } \\
4 \text { 力月 }\end{array}$ & 338日 & 3 回 & 20日 & $\begin{array}{l}\text { 背側凸 } 43^{\circ} \\
\text { 橈側凸 } 22^{\circ}\end{array}$ & 橈側凸 $15^{\circ}$ & 橈側凸 $7^{\circ}$ \\
\hline 7 & $\begin{array}{l}1 \text { 才 } \\
9 \text { 力月 }\end{array}$ & $\begin{array}{c}2 \text { 才 } \\
10 \text { 力月 }\end{array}$ & 416日 & 2 回 & 11日 & 背側凸 $25^{\circ}$ & 背側凸 $10^{\circ}$ & 背側凸 $5^{\circ}$ \\
\hline 8 & $3 才$ & $\begin{array}{l}4 \text { 才 } \\
5 \text { 力月 }\end{array}$ & 537日 & 3 回 & 21日 & $\begin{array}{l}\text { 背側凸 } 25^{\circ} \\
\text { 尺側凸 } 20^{\circ}\end{array}$ & $\begin{array}{l}\text { 背側凸15ํ } \\
\text { 橈側凸 } 7^{\circ}\end{array}$ & $(-)$ \\
\hline 9 & $\begin{array}{l}1 \text { 才 } \\
9 \text { 力月 }\end{array}$ & $\begin{array}{l}2 \text { 才 } \\
9 \text { 力月 }\end{array}$ & 349日 & 2 回 & 18日 & $\begin{array}{l}\text { 背側凸 } 15^{\circ} \\
\text { 橈側凸 } 20^{\circ}\end{array}$ & $\begin{array}{l}\text { 背側凸10 } \\
\text { 橈側凸15。 }\end{array}$ & $\begin{array}{l}\text { 背側凸 } 9^{\circ} \\
\text { 橈側凸 } 3^{\circ}\end{array}$ \\
\hline
\end{tabular}

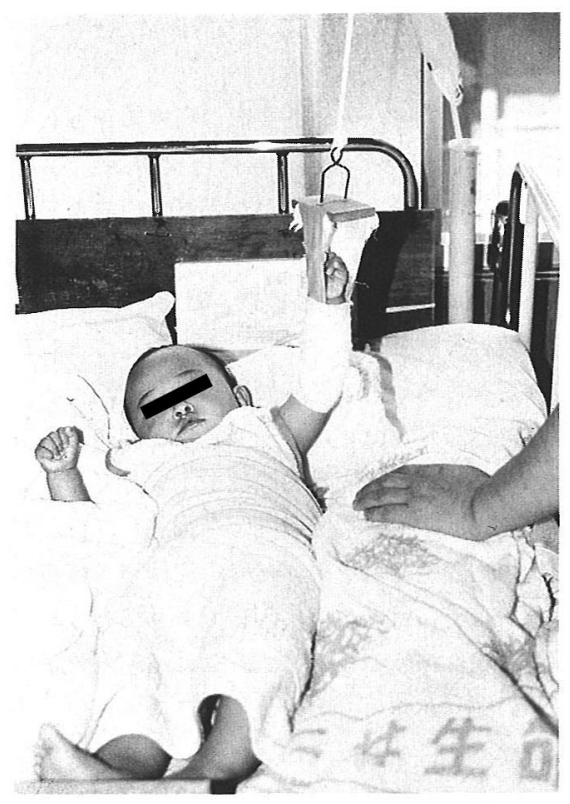

図11才 8 力月 女 徒手整復後牽引中

経過観察期間は 338 日から 1757 日,平均 818.8 日であ った。

$$
\text { 結果 }
$$

症例ごとの初診時変形および最終経過観察時におけ る変形を示す(表 1 ). 10 度以上の屈曲変形を残したも のは 1 例もなく可動域制限, 神経麻痺などもみられず

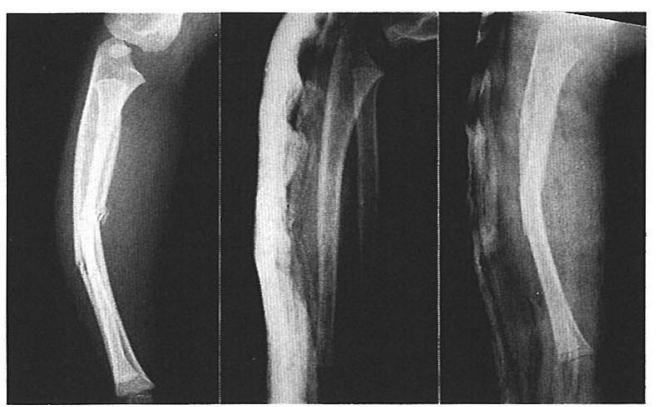

初診時

徒手整復直後

再転位時

図 2 症例 2 才 9 力月 男 受傷当日受診した。 当日徒手整復し alignment 良好となったが再転 位をきたした。

機能的に問題なく治癒した。症例を供覧する。

症例 $2: 3$ 才 9 力月, 男子. 転倒し受傷, 当日当院 受診した。初診時レントゲンにて右前腕中 $1 / 3$ での背 側凸変形 20 度 橈側凸変形 25 度を伴った若木骨折で あった。徒手整復後ギプス副子固定するも受傷後 1 週 間目に再転位をきたし再整復をおこなった。しかし受 傷後 12 日目で再転位を来したため（図 2 ） 3 度目の整 復をおこないその後 21 日間の牽引療法を行った(図 3 )。 受傷後 6 週目のレントゲンでは背側凸変形 5 度, 橈側 凸変形 12 度の変形を認めたが受傷後 2 年 1 力月の最終 経過観察時レントゲンで変形なく機能的に問題ない(図 4 ). 


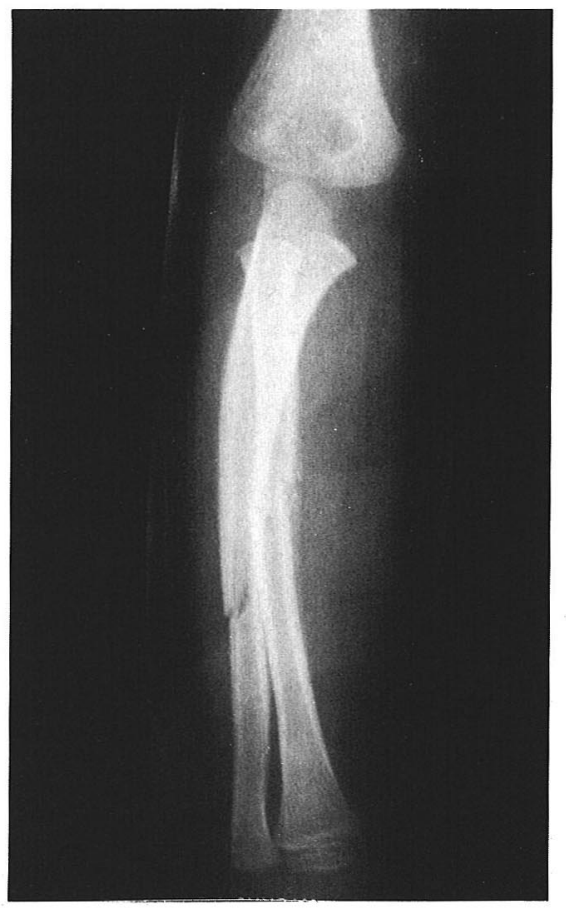

図 3 症例 2 受傷後 12 日目に 3 度目の整復を扝こな い22 日間の牽引療法をおこなった。

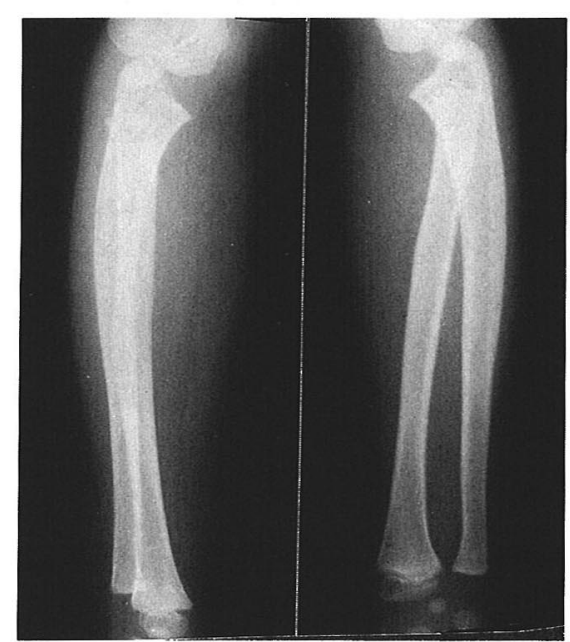

図 4 症例 2 受傷後 2 年 1 力月の最終経過観察時 レントゲンで変形は認めない。

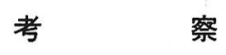

前腕は橈骨と尺骨により構成されており回内，回外
表 2 中央 $1 / 3$ ・骨幹部骨折の変形の許容度

\begin{tabular}{ll}
\hline \hline King : & 8 才を越すと矯正少ない \\
Cave : & 15 度まで \\
Hogstrom : & 10 才末満は10度まで \\
Daruwalla : & 10 才を越すと10度末満 \\
Kay : & $\quad$ " \\
Fuller : & 8 才以上は解剖学的整復 \\
\hline
\end{tabular}

運動が可能である.この回旋運動に際しては, 近位で は橈骨頭の回転により，遠位では橈骨が尺骨頭のまわ りを回転し，尺骨はその反対方向へ軽度回転するとい われている。成人においては橈骨は約 9.3 度の橈側凸, 約 6.4 度の背側凸彎曲を有し，尺骨は軽度の橈側凸へ の彎曲を有している。前腕回旋運動確保のためにはこ れらの形態維持は重要で骨折整復時には念頭におかな ければならない ${ }^{5)}$. 許容される変形以内に整復固定を行 うことはまさにこの回旋運動の獲得のためにあり, 自 家矯正力による remodelling が期待できる乳幼児とい えども中央 $1 / 3$ では 10 度以内の変形にとどめるべきで ある4)6) (表 2 )。

一般に屆伸方向への屈曲変形は自家矯正されやすい が,橈尺方向の変形や回旋変形は自家矯正されにくい1). 整復固定に際し種々の工夫がなされているがその主な 目的は再転位をいかに防止するかであり, DePalma ら や Kingによれば, 徒手整復後, 时 90 度屈曲, 前腕中 間位で前腕骨間腔を保持させる工夫をして上腕からギ プス固定を行い経時的X線撮影で再転位をチェックし ている ${ }^{3) 6)}$ 。また Rang は最初の変形が回内変形か回外 変形かによって整復固定の肢位を工夫している77. 外固 定に際してはいずれも 3 点固定を強調しているが，最 近の新しい固定材料を用いても，乳幼児で緩みのこな い固定を確実に行うことは困難であり,どうしても固 定中の再転位が起こりやすく，これは若木骨折ではと くにその傾向が強い. 牽引療法はこの再転位を防止す る簡単な方法であり, 乳幼児をベッドに $2 \sim 3$ 週間拘 束することが困難ではないかと危惧したが，実際には ほとんど困った症例はなかった。これは子供が意外と その置かれた立場に順応するためと思われた。

$$
\text { ま と め }
$$

1. 乳幼児の両前腕骨骨幹部骨折 9 例に対して, 整 復後垂直牽引を施行し良好な結果を得た。

2. 他の療法に見られるような再転位は 1 例もなく， 再転位防止には有用な方法である。 
文

献

1）安藤 正・他：前腕骨骨折. 整・災外, $28: 867-878$, 1985.

2) Blount, W. P.: Fractures in Children. Williams and Wilkins, Baltimore, 1985.

3） DePalma・他：図説骨折・脱臼の管理. 阿部光俊（監 訳), 1 巻, 広川書店, 東京, 1986 .

4) Fuller, D. J., et al. : Malunited fractures of the forearm in Children. J. Bone Joint Surg., 64-B : 364 $-367,1982$.

5）生田義和・他：前腕骨骨幹部骨折の治療。整・災外, 32 : 1257-1266, 1989.

6) King, R. E., et al : Fractures in Children. J. B. Lippincott, Philadelphia, 1984.

7) Rang, M. C. : Children's Fractures. 2nd. Ed. J. B. Lippincott, Philadelphia, 1983.

質 問

長崎大学 伊藤 信之

前腕の変形はどの程度までゆるせるものでしょうか. すなわち将来の ADL 障害を生じるのに何度位の変形で 生じるでしょうか.

年令の問題もありむずかしいこととは思いますが.

\section{解 答宮城病院 久賀養一郎}

前腕中 $1 / 3$ 部での変形の許容度は, 文献では乳幼児 では 10 度以下としているものが多いようです.これは 回内, 回外制限を防止する意味で, 重要と思われます。 われわれも 10 度をこえるような変形に対しては整復を 行います。

※共同演者 井上博の発言あり
発 言

筑豊労災病院 井上 博

共同演者として

中央 $1 / 3$ 部骨折は幼児といえども機能的な点からみ て，許容範囲は非常に小さいというのが大方の文献的 同意のようです．多方向への変形がありますが，尺側 凸の変形の残存が機能的に最とも悪いという報告もあ ります.このようなことから，あらゆる方向への変形 を矯正した方がよいであろうと思っております。

質 問国立小浜病院 平松 隆

(1) 牽引の目的は(1)整復か ? (2)整復後の再転位防止 なのでしょうか.

(2) 徒手整復とは再骨折をおこさせるという意味で しょうか.

解 答 宮城病院 久賀養一郎

牽引療法に際しては, 全例徒手整復後におこなって おります，仮骨ができた症例に対しては仮骨を再骨折 させ,整復位保持のため牽引療法をおこなっています。 牽引のみによって矯正を試みた例はありませんでした。

質 問 福岡大学 竹下 満

牽引は中間位でされているのですか

解 答 宮城病院 久賀養一郎 前腕中間位保持はまず徒手整復後にギプス副子固定 にて行い，再転位をきたした症例に対して中間位で牽 引療法をおこなっております。とくに回外位にはして おりません。 